\title{
The utility of B-type natriuretic peptide in the diagnosis of heart failure in the emergency department: a systematic review Deborah Korenstein*1, Juan P Wisnivesky ${ }^{1,2}$, Peter Wyer ${ }^{3}$, Rhodes Adler ${ }^{1}$, Diego Ponieman ${ }^{1}$ and Thomas McGinn ${ }^{1}$
}

\author{
Address: ${ }^{1}$ Division of General Internal Medicine, Department of Medicine, Mount Sinai School of Medicine, New York, USA, ${ }^{2}$ Pulmonary Division, \\ Department of Medicine, Mount Sinai School of Medicine, New York, USA and ${ }^{3}$ Emergency Medicine Residency Program, New York Presbyterian \\ Hospital, New York, USA \\ Email: Deborah Korenstein* - deborah.korenstein@mssm.edu; Juan P Wisnivesky - juan.wisnivesky@mssm.edu; \\ Peter Wyer - pwyer@worldnet.att.net; Rhodes Adler - rhodes.adler@mssm.edu; Diego Ponieman - diego.ponieman@mssm.edu; \\ Thomas McGinn - thomas.mcginn@mssm.edu \\ * Corresponding author
}

Published: 26 June 2007

BMC Emergency Medicine 2007, 7:6 doi:10.1186/1471-227X-7-6
Received: 5 December 2006

Accepted: 26 June 2007

This article is available from: http://www.biomedcentral.com/I47I-227X/7/6

(c) 2007 Korenstein et al; licensee BioMed Central Ltd.

This is an Open Access article distributed under the terms of the Creative Commons Attribution License (http://creativecommons.org/licenses/by/2.0), which permits unrestricted use, distribution, and reproduction in any medium, provided the original work is properly cited.

\begin{abstract}
Background: Dyspnea is a common chief complaint in the emergency department (ED); differentiating heart failure (HF) from other causes can be challenging. Brain Natriuretic Peptide (BNP) is a new diagnostic test for HF for use in dyspneic patients in the ED. The purpose of this study is to systematically review the accuracy of BNP in the emergency diagnosis of HF.
\end{abstract}

Methods: We searched MEDLINE (1975-2005) supplemented by reference tracking. We included studies that reported the sensitivity and specificity of BNP for diagnosing HF in ED patients with acute dyspnea. Two reviewers independently assessed study quality. We pooled sensitivities and specificities within five ranges of BNP cutoffs.

Results: Ten studies including 3,344 participants met inclusion criteria. Quality was variable; possible verification or selection bias was common. No studies eliminated patients with obvious medical causes of dyspnea. Most studies used the Triage BNP assay; all utilized a clinical reference standard. Pooled sensitivity and specificity at a BNP cutoff of $100-105 \mathrm{pg} / \mathrm{ml}$ were $90 \%$ and $74 \%$ with negative likelihood ratio (LR) of 0.14 ; pooled sensitivity was $81 \%$ with specificity of $90 \%$ at cutoffs between 300 and $400 \mathrm{pg} / \mathrm{ml}$ with positive LR of 7.6.

Conclusion: Our analysis suggests that BNP has moderate accuracy in detecting HF in the ED. Our results suggest utilizing a BNP of less than $100 \mathrm{pg} / \mathrm{ml}$ to rule out HF and a BNP of greater than $400 \mathrm{pg} / \mathrm{ml}$ to diagnose HF. Many studies were of marginal quality, and all included patients with varying degrees of diagnostic uncertainty. Further studies focusing on patients with diagnostic uncertainty will clarify the real-world utility of BNP in the emergency management of dyspnea. 


\section{Background}

Heart failure (HF) is a major public health problem in the United States whose incidence has been rising in recent years $[1,2]$. Twelve to 15 million office visits and 6.5 million hospital days are attributable to HF each year, and HF is responsible for more Medicare expenditure than any other diagnosis[3].

While common, HF can be difficult and time consuming to diagnose, with no available single definitive test. Brain Natriuretic Peptide (BNP) is released by the ventricle in response to increased volume or pressure, and has been noted to be elevated in patients with $\mathrm{HF}$, offering promise as a quantitative diagnostic test for the disease. Beginning in the mid-1990s, BNP has been evaluated as a diagnostic test for HF in various settings, including primary care and urgent care. In more recent years its use has become widespread in emergency departments in the evaluation of acute dyspnea. While the FDA and other organizations in North America and Europe have recommended its inclusion in the workup of $\mathrm{HF}$, others have commented that the utility of BNP is not yet clear from the available literature $[4,5]$.

We conducted a systematic review of the literature to summarize the available evidence about the sensitivity and specificity of brain natriuretic peptide in the diagnosis of heart failure in the emergency department.

\section{Methods}

We used systematic methods to identify relevant studies, determine study eligibility, evaluate study methodological quality, and summarize findings regarding diagnostic accuracy [6-9].

\section{Data sources and study eligibility}

We conducted a literature search of MEDLINE (19752005) using combinations of the key words diagnosis, heart failure, congestive heart failure, BNP, natriuretic peptide or peptides, and dyspnea. The search was constructed to retrieve articles which included the key words "CHF", "heart failure" or "congestive heart failure", along with "BNP", "natriuretic peptide" or "natriuretic peptides", and either "dyspnea" or "diagnosis" and was limited to human subjects. We augmented our computerized literature search by manually reviewing the reference lists of identified studies and of other published reviews $[5,10,11]$. We included articles published in any language.

Two investigators independently evaluated potential articles to decide if they were eligible for inclusion in the systematic review. Disagreements were resolved by discussion. Studies were considered eligible for inclusion if they 1) addressed the usefulness of BNP to quantify the probability of HF among patients presenting with acute dyspnea to an emergency department setting 2) included at least 50 patients and if 3 ) the absolute numbers of truepositive, false-negative, true-negative, and false-positive observations were available or derivable for the data presented. Articles assessing the accuracy of N-terminal probrain natriuretic peptide (NT-proBNP) were excluded, as NT-proBNP represents a distinct diagnostic test with its own performance characteristics. We attempted to contact authors of potential articles to provide any missing information. In cases of articles with overlapping study subjects, we chose either the article with more complete information or the article with the larger number of included participants.

HF is a clinical syndrome which can be challenging to diagnose, and there is no single test which serves as the criterion standard for its diagnosis [10,12]. We therefore included studies with a clinical criterion standard, in which the diagnosis of HF was determined by one or more expert cardiologists with access to all clinical information, including assessment of ventricular function and symptomatic response to treatment.

\section{Assessment of study quality}

The methodological quality of the selected studies was assessed, and data were abstracted independently by 2 reviewers (DK and TM). We assessed study quality using the QUADAS[13]method. We utilized an adapted checklist which excluded items for which articles had been preselected or which were not applicable. Discrepancies were resolved by consensus.

Variables extracted included the study design, the number of patients with and without $\mathrm{HF}$, characteristics of the study population (age distribution, gender, and ethnicity), clinical variables evaluated and whether they were clearly defined, reference standard utilized, and the diagnostic performance of BNP.

The optimal design for assessing the accuracy of a diagnostic test is considered to be a prospective blind comparison of the test and the reference standard in a consecutive series of patients from a relevant clinical population $[6,14]$. To assess the quality of the studies included in the meta-analysis data were collected regarding the study design, reference standard, adequacy of patient spectrum, description of the reasons for patient withdrawals, and the presence of verification or selection bias. An adequate description of the spectrum of patients included in a study can help clinicians know whether to generalize the results to their patients. We considered that a study met this criterion if the following information was provided about the study population: 1) demographics including age, gender and racial distribution, 2) proportion of patients 
with history of HF and either asthma or COPD, and 3) the number of patients hospitalized.

Verification bias occurs if the decision to perform the reference test is based on the result of the test under study. For instance, if patients with positive, as opposed to negative, BNP preferentially receive the criterion standard evaluation, the sensitivity of the test can be falsely elevated because of the incorrect exclusion of false negatives from the analysis. In cases in which not all patients were subjected to the reference test, the study was scored as having verification bias[15].

Selection bias can be present when not all patients presenting with the relevant condition are included in order of entry (consecutive) into the study, or when this selection is not random. If it was not clear from the text that a consecutive series of patients was included or a random subset, the corresponding study was scored as non-consecutive.

\section{Statistical analysis}

To evaluate agreement between raters for the assessments of study quality, we calculated the observed percentage agreement and the $\kappa$ coefficient for interrater reliability[16].

The results of diagnostic tests with numerical results can be conceived not as dichotomously "positive" or "negative," but in a continuous fashion, in which different results may impact pre-test probability to different degrees. Under these circumstances interval likelihood ratios (LR) can be calculated for ranges of values; for example, there might be a LR associated with a BNP between 100 and $200 \mathrm{pg} / \mathrm{ml}$ which reflects the impact on pre-test probability of a BNP greater than 100 but less than 200. The raw data required to calculate interval LRs was not available to us for all studies. Data was only available to calculate pooled LRs. Data at different dichotomous BNP cutoffs; i.e. for a BNP greater than or less than a particular value. We grouped these cutoffs into ranges and pooled data from any study that reported sufficient data to construct a 2 by 2 table for a cutoff value within that range.

For each study, we recorded the true-positive rate (sensitivity) and the true negative rate (specificity) for various cutoff values of BNP as provided by each study. The heterogeneity of all indexes was evaluated using a homogeneity test based on the $\chi^{2}$ test. A result of $p<0.1$ was considered significant given the relatively low power of this test. In addition, the $I^{2}$ statistic was calculated to assess the impact of heterogeneity on the results. This statistic describes the percentage of the variability in effect estimates that it is due to heterogeneity rather than sampling error (chance).
A $I^{2}$ value of $0 \%$ represents no heterogeneity and 25,50 , and $75 \%$ indicate low, moderate, and high heterogeneity[17]. We planned to pool data regardless of heterogeneity so that clinicians could have an overall estimate of the performance of this diagnostic test, although heterogeneity may limit the validity of the pooled estimate.

We pooled data from different studies by grouping their results within five ranges of BNP cutoffs in $\mathrm{pg} / \mathrm{ml}$ : $50-80$, 100-105, 150-199, 200-299 and 300-400. For each range of BNP cutoff, we included data from any study that reported sensitivity and specificity for BNP values in that range. When studies reported results for more than one cutoff in the range, we used the cutoff which was closest to the middle of the range. We utilized the Random Effects Model to calculate pooled LRs for each BNP cutoff[18]. These LRs can be used to interpret values greater than or less than a BNP in each cutoff range; they can not be utilized to precisely interpret a BNP value within each cutoff range.

To assess publication bias, we created a funnel plot of individual study log odds ratios plotted against a function of the sample size as described by Deeks et al [19]. We tested for funnel plot asymmetry based on a regression of standardized effect estimates against precision to evaluate whether the intercept deviates from zero[20].

Statistical analyses were performed using SAS version 9.0 (SAS Institute, Cary, NC).

\section{Results \\ Selection of studies}

Figure 1 outlines the flow of article retrieval for the review. Of the ten included articles, nine were published in English and one was published in French[21]. Data from the French article was extracted by one of the investigators (DK) who speaks French, and was excluded from the kappa calculation. Several studies reported results for overlapping patient populations [21-32]. Eight studies reported results from the BNP Multinational Study[23,24,28-31,33,34]. To avoid duplication, we retained the report in the New England Journal of Medicine [29] as it included the most complete description of demographics and BNP performance characteristics. The patients reported on in the study by Dao[25] et al were a subset of the patients in the study by Morrison et al[5,32], so we retained only the Morrison report. The two publications by Ray $[35,36]$ reported on the same set of patients, so we retained the larger report. Of the ten studies in the analysis, none eliminated patients with obvious HF or lung disease. Many studies included incomplete reports of demographic and other information. The characteristics of the studies analyzed are outlined in Table $1[21,26,29,32,36-42]$. 


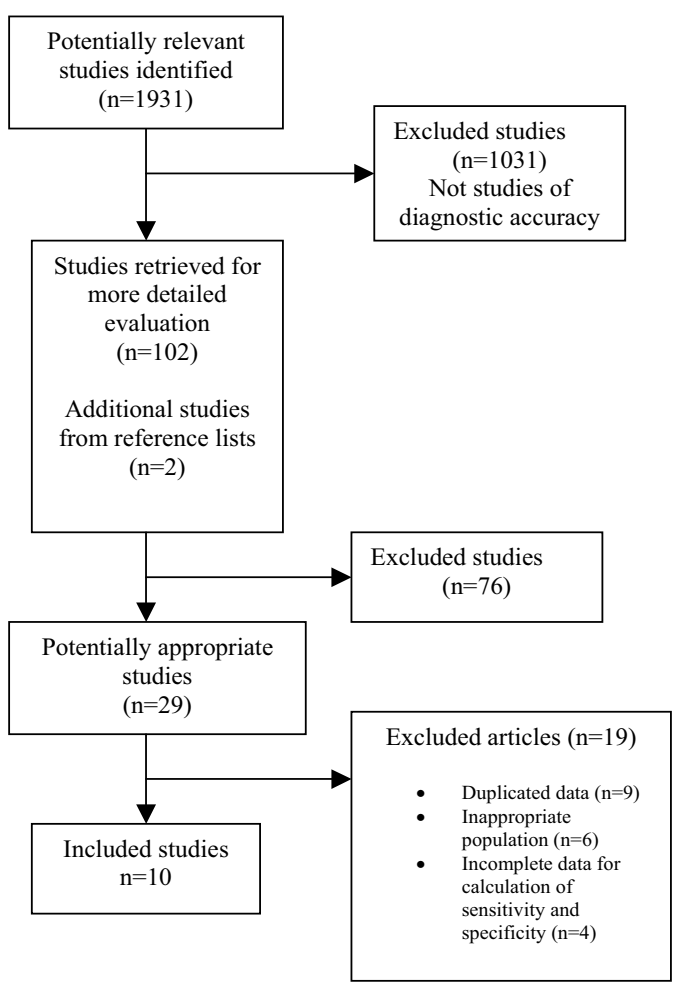

Figure I

Flow of studies in the review.
The ten studies in the systematic review included 3,344 participants in North America, South America, New Zealand and Europe. The mean age of participants ranged from 64 to 80 years and between $45 \%$ and $93 \%$ of the participants were men. Nine of the ten studies utilized the Triage BNP Assay[26,29,32,36-40], which is widely used and commercially available. The other used the AxSYM BNP assay[41](table 1). In seven studies the expert opinion of two or more cardiologists with access all available clinical data served as the reference standard for the diagnosis of HF; three studies $[21,40,41]$ utilized the opinion of only one cardiologist.

The spectrum of patients appears to be quite broad in most studies. Most included primarily older patients; gender distribution varied widely. Between 43 and 100\% of enrolled patients were admitted to the hospital. Since hospital admission criteria are often subjective and may vary across health care systems, these rates may be due to practice variation or to variability in disease severity across the studies. Patients with obvious trauma as a cause of dyspnea were excluded from all studies, while all studies included patients with an obvious medical cause (i.e. asthma exacerbation, COPD or HF) of their symptoms. Thus, the patients included in our analysis represent a population of patients presenting to the emergency department with dyspnea, with varying degrees of diagnostic uncertainty.

Methodological quality and study characteristics

The observed inter-rater agreement for assessment of study quality was $\kappa=.88[30]$. The results of the quality

Table I: Characteristics of the studies included in the review

\begin{tabular}{|c|c|c|c|c|c|c|c|c|c|c|c|}
\hline $\begin{array}{l}\text { Study } \\
\text { Year }\end{array}$ & $\begin{array}{c}\# \\
\text { subjects }\end{array}$ & $\begin{array}{c}\text { Age } \\
\text { (mean } \\
+/- \text { SD) }\end{array}$ & $\begin{array}{c}\% \\
\text { male }\end{array}$ & $\begin{array}{c}\text { History } \\
\text { of HF } \\
(\%)\end{array}$ & $\begin{array}{c}\text { History } \\
\text { of asthma } \\
\text { or COPD } \\
(\%)\end{array}$ & $\begin{array}{c}\text { Patients } \\
\text { admitted } \\
(\%)\end{array}$ & $\begin{array}{l}\text { BNP } \\
\text { assay } \\
\text { used }\end{array}$ & $\begin{array}{c}\text { Final diag- } \\
\text { nosis HF (\%) }\end{array}$ & $\begin{array}{l}\text { Cutoff } \\
\text { (pg/ml) }\end{array}$ & $\begin{array}{c}\text { Sensi- } \\
\text { tivity } \\
(\%)\end{array}$ & $\begin{array}{c}\text { Speci- } \\
\text { ficity (\%) }\end{array}$ \\
\hline $\begin{array}{l}\text { Jourdain } \\
2002\end{array}$ & 125 & $72 \dagger$ & $*$ & $*$ & $*$ & 100 & Triage & 72 & 300 & 94 & 86 \\
\hline $\begin{array}{l}\text { Logeart } \\
2002\end{array}$ & 163 & $67 \pm 15$ & 67 & 49 & $*$ & 90 & Triage & 71 & 100 & 96 & 31 \\
\hline Maisel 2002 & 1,586 & $64 \pm 17$ & 56 & 33 & 41 & 72 & Triage & 47 & 100 & 90 & 76 \\
\hline $\begin{array}{l}\text { Morrison } \\
2002\end{array}$ & 321 & $*$ & 95 & 42 & 40 & 43 & Triage & 42 & 105 & 86 & 94 \\
\hline $\begin{array}{l}\text { Villacorta } \\
2002\end{array}$ & 70 & $72 \pm 16$ & 47 & 37 & 44 & $*$ & Triage & 51 & 200 & 100 & 97 \\
\hline $\begin{array}{l}\text { Lainchbury } \\
2003\end{array}$ & 205 & $70 \pm 14$ & 49 & 25 & 42 & $*$ & Triage & 34 & 100 & 77 & 84 \\
\hline $\begin{array}{l}\text { Knudsen } \\
2004\end{array}$ & 155 & $76 \dagger$ & 45 & $*$ & 47 & $*$ & Triage & 48 & 100 & 90 & 55 \\
\hline Ray 2004 & 308 & $80 \pm 8$ & 50 & 20 & 25 & 100 & Triage & 46 & 100 & 90 & 59 \\
\hline $\begin{array}{l}\text { Mueller } \\
2005\end{array}$ & 251 & $73 \dagger$ & 93 & 65 & $*$ & $*$ & $\begin{array}{c}\text { AxSYM } \\
\text { BNP }\end{array}$ & 55 & 100 & 96 & 61 \\
\hline Alibay 2005 & 160 & $80 \pm 14$ & 48 & 38 & 34 & 58 & Triage & 38 & 150 & 94 & 61 \\
\hline
\end{tabular}

Sensitivity and Specificity are presented for the BNP value closest to $100 \mathrm{pg} / \mathrm{ml}$ from each study.

$*$ Not reported + Standard deviation not reported 
assessment of the included studies are listed in table 2. Only one of the studies (10\%) clearly defined its spectrum of patients[29]. In all ten studies the diagnosis of HF was determined without knowledge of the BNP (blinding). Selection bias was clearly absent in six studies (60\%). The presence of verification bias was difficult to ascertain in most of the studies, but was possible in three (30\%). One study (10\%) had unexplained patient withdrawals[21]. No study reported inter-reader reliability for the reference standard (kappa), and no evaluated study met all quality criteria.

A funnel plot did not suggest evidence of publication bias.

\section{Diagnostic accuracy}

The sensitivity and specificity of BNP for diagnosing HF varied (Table 1), and statistically significant heterogeneity was present $\left(\mathrm{p}<.05, I^{2}>0.5\right)$. Many studies reported sensitivity and specificity of BNP using the cutoff value with the greatest combined sensitivity and specificity, while many reported sensitivity and specificity using a cutoff at or near $100 \mathrm{pg} / \mathrm{ml}$, which has become the conventional threshold for a positive test. Sensitivity at or near a BNP cutoff of $100 \mathrm{pg} / \mathrm{ml}$ ranged from $86 \%$ to $96 \%$. Specificity at this cutoff ranged from $31 \%$ to $94 \%$. Pooled negative LR for this range was .14 by the random effects model (Table 3). Sensitivity was not appreciably higher at lower cutoffs in most studies[26,29,38,39]. Several studies evaluated performance characteristics at higher BNP cutoffs, up to 400. At BNP cutoffs of 150-199 pg/ $\mathrm{ml}[26,29,32,36,37,39,41]$, sensitivity was between $85-$ $94 \%$ and specificity ranged widely from $45-85 \%$. BNP cutoff values between 200 and $299 \mathrm{pg} / \mathrm{ml}$ had sensitivities between 78 and 100\% and specificities between 66 and $97 \%[26,32,36,39,41]$. Only 3 studies[21,36,39] evaluated cutoffs above 299; cutoffs of 300-400 pg/ml had sen- sitivity of $67-94 \%$ and specificity between 84 and $92 \%$, with a pooled positive LR of 7.6 (Table 3 ). Pooled LRs for each range of cutoff values are shown in table 3.

\section{Discussion}

The current study presents a systematic review of the literature on the accuracy of B-type natriuretic peptide for diagnosing $\mathrm{HF}$ in the emergency department. Our review differs from others which have addressed this issue. The review by Schwam[5] described the individual studies in detail but did not systematically assess their quality. A recent review by Wang et al[10] performed quality assessments but did not report all aspects of study quality. A review by Doust et al[11] performed quality assessments and pooled data across studies, but calculated a pooled diagnostic odds ratio, which is not directly applicable to clinical practice. As the use of BNP has become increasingly common, we feel there is a need for quality assessed pooled data for clinical application. Our review is the first to present a complete quality assessment of the included articles and to pool data in a way that is relevant to practicing clinicians.

A BNP of $100 \mathrm{pg} / \mathrm{ml}$ is often cited as the best cutoff for the diagnosis of HF[43]. We found a pooled positive LR of 3.4 and negative LR of .14. At higher cutoffs of between 300 and $400 \mathrm{pg} / \mathrm{ml}$, the positive LR rises to 7.6, with a negative LR of .17. Thus, our analysis suggests that among adult patients who with suspected heart failure, a low BNP seems to make HF unlikely, and very high BNP makes HF likely. BNP values between 100 and 300 pg/ml may not be helpful in diagnosing HF.

Table 4 demonstrates the utility of BNP in diagnosing HF in the context of varying pre-test probabilities. With a pretest probability of $10 \%$ or $30 \%$, a BNP of $<105 \mathrm{pg} / \mathrm{ml}$

Table 2: Quality measures of included studies

\begin{tabular}{|c|c|c|c|c|c|c|c|}
\hline Study, Year & $\begin{array}{l}\text { Were } \\
\text { important } \\
\text { inclusions and } \\
\text { exclusions } \\
\text { explained? }\end{array}$ & $\begin{array}{l}\text { Was patient } \\
\text { spectrum } \\
\text { clearly } \\
\text { defined?* }\end{array}$ & $\begin{array}{l}\text { Was the diagnosis } \\
\text { of HF determined } \\
\text { without } \\
\text { knowledge of the } \\
\text { BNP result? }\end{array}$ & $\begin{array}{l}\text { Was } \\
\text { agreement } \\
\text { reported for } \\
\text { the reference } \\
\text { standard? }\end{array}$ & $\begin{array}{l}\text { Was selection } \\
\text { bias present? }\end{array}$ & $\begin{array}{l}\text { Was } \\
\text { verification } \\
\text { bias } \\
\text { present? }\end{array}$ & $\begin{array}{l}\text { Were } \\
\text { withdrawals } \\
\text { explained? }\end{array}$ \\
\hline Jourdain 2002 & Yes & No & Yes & No & No & No & No \\
\hline Logeart 2002 & Yes & No & Yes & No & No & No & Yes \\
\hline Maisel 2002 & Yes & Yes & Yes & No & Possible & No & N/At \\
\hline Morrison 2002 & Yes & No & Yes & No & Yes & No & N/A $\dagger$ \\
\hline Villacorta 2002 & Yes & No & Yes & No & No & No & N/A $\dagger$ \\
\hline $\begin{array}{l}\text { Lainchbury } \\
2003\end{array}$ & No & No & Yes & No & Possible & Possible & N/At \\
\hline Knudsen 2004 & Yes & No & Yes & No & No & Possible & N/A \\
\hline Ray 2004 & Yes & No & Yes & No & Possible & No & Yes \\
\hline Alibay 2005 & Yes & No & Yes & No & No & No & N/A \\
\hline Mueller 2005 & Yes & No & Yes & No & No & No & Yes \\
\hline
\end{tabular}

*Information available on age, gender, race, prevalence of a HF history and history of asthma and/or COPD, and the percentage of patients admitted to the hospital. 
Table 3: Pooled LRs for BNP in emergency department settings

\begin{tabular}{cccc}
\hline $\begin{array}{c}\text { BNP cutoff } \\
\text { (pg/ml) }\end{array}$ & $\begin{array}{c}\text { Number of studies/ } \\
\text { number of patients with } \\
\text { information on this cutoff }\end{array}$ & $\begin{array}{c}\text { Positive } \\
\text { LR }\end{array}$ & $\begin{array}{c}\text { Negative } \\
\text { LR }\end{array}$ \\
\hline $50-80$ & $4 / 2109$ & 2.4 & .08 \\
$100-105$ & $7 / 2989$ & $3.4 \ddagger$ & $.14 \ddagger$ \\
$150-199$ & $8 / 2944$ & 3.8 & .16 \\
$200-299$ & $6 / 1268$ & 4.6 & .16 \\
$300-400$ & $3 / 596$ & $7.6 \ddagger$ & $.17 \ddagger$ \\
\hline
\end{tabular}

$\ddagger$ LR from random effects model

results in a probability of $\mathrm{HF}$ of $2 \%$ or $5 \%$ respectively and is clinically useful in ruling out HF. A higher pre-test probability of 70\% coupled with the same low BNP results in a $25 \%$ chance of $\mathrm{HF}$, which is less definitive and may result in further diagnostic testing. A very high pre-test probability of $90 \%$ and a low BNP results in a $56 \%$ likelihood of HF. Similarly, a diagnosis of HF can be made in a patient with a high $(70 \%$ or $90 \%)$ pre-test probability and an elevated BNP of $>300 \mathrm{pg} / \mathrm{ml}$; while an elevated BNP in a patient with a low $(30 \%)$ pre-test probability leads to a $77 \%$ chance of HF and might result in further diagnostic testing.

Several limitations of the evaluated studies should be considered. First, there were potential methodological issues including possible selection bias in many of the studies and verification bias in a few. No studies reported interrelater agreement for the reference standard, and a few studies failed to clarify important inclusion and exclusion criteria. Most important, however, may be the issue of spectrum. In studies of diagnostic tests, it is important that investigators enroll patients in whom there is diagnostic uncertainty [44], in whom the test would be used in clinical practice. The studies of BNP recruited broadly, and likely included patients in whom there was diagnostic uncertainty in addition to patients in whom the diagnosis was clear. For example, some patients presenting with dyspnea certainly had obvious asthma exacerbations, and these patients were included in the studies of BNP although they are not patients in whom a BNP assay would be utilized in clinical practice. The broadness of the spectrum in this case may have resulted in a biased esti-

Table 4: Impact of high and low BNP results on pre-test probabilities

\begin{tabular}{ccc}
\hline $\begin{array}{c}\text { Pre-test } \\
\text { probability }\end{array}$ & $\begin{array}{c}\text { Post-test probability } \\
\text { for BNP < I 05 pg/ml }\end{array}$ & $\begin{array}{c}\text { Post-test probability } \\
\text { for BNP > 300 pg/ml }\end{array}$ \\
\hline $10 \%$ & $2 \%$ & $46 \%$ \\
$30 \%$ & $5 \%$ & $77 \%$ \\
$50 \%$ & $12 \%$ & $88 \%$ \\
$70 \%$ & $25 \%$ & $95 \%$ \\
$90 \%$ & $56 \%$ & $99 \%$ \\
\hline
\end{tabular}

mation of the accuracy of the diagnostic test[44,45]. This potential bias limits the applicability of the included studies and of our analysis to clinical practice. Some investigators explored the impact of this broad spectrum by performing sub-group analysis looking only at patients in whom there was diagnostic uncertainty. In the Breathing Not Properly study, BNP did perform well in the subset of patients with a history of pulmonary disease[30] with sensitivity and specificity of $93 \%$ and $77 \%$ at a cutoff of 100 $\mathrm{pg} / \mathrm{ml}$, similar to that of the larger population. This finding suggests that accuracy of BNP as determined by the studies overall may in fact reflect the accuracy of the test in patients in whom there is a high degree of diagnostic uncertainty. We look forward to a confirmation of these findings in other populations.

The best evidence in support of the widespread use of a new diagnostic test is a randomized trial demonstrating that its use improves quality of care. $[46,47]$ In the case of $\mathrm{BNP}$, such a trial has already been published. In the B-type Natriuretic Peptide for Acute Shortness of Breath Evaluation (BASEL) Study[48] Mueller and colleagues performed a single-blind randomized trial in Switzerland in which patients presenting the emergency department with acute dyspnea were assigned to a diagnostic strategy including a single bedside BNP measurement or a "standard" diagnostic strategy which excluded BNP. As in the studies included in our analysis, patients with obvious trauma were excluded. A total of 452 patients were randomized; $58 \%$ were men and the mean age was 71 years. Clinicians were given guidelines for the interpretation of $B N P$ values. A BNP level of $<100 \mathrm{pg} / \mathrm{ml}$ indicated that HF was unlikely and other causes of dyspnea should be investigated while a BNP $>500 \mathrm{pg} / \mathrm{ml}$ made HF the most likely diagnosis. No strong conclusions about HF were recommended for patients with values between 100 and $500 \mathrm{pg} /$ $\mathrm{ml}$. The study found lower rates of hospital admission ( $75 \%$ vs. $85 \%)$, significant reductions in time to discharge ( 8 vs. 11 days) and an $\$ 1850$ reduction in cost in the group randomized to BNP testing. In-hospital and 30-day mortality were not significantly different in the two groups.

On initial inspection these strongly positive results seem inconsistent with our findings that BNP is only a moderately accurate diagnostic test. In fact, some have criticized the BASEL study [49]. Patients enrolled in the study received somewhat scripted care, which may have included testing that is not routinely performed [50]. The specific nature of the care of patients in each group and the diagnostic tests they received was not described in the publication [48]. The severity of illness in the study group is also striking. Although presenting symptoms seemed moderate, $80 \%$ of enrolled patients were hospitalized, of whom $20 \%$ were admitted to the intensive care unit, and 
the median length of stay in the control group was 11 days. While these characteristics may be related to the standards of practice in Switzerland or to the particulars of the study, it is unclear whether the population evaluated is representative of the broad group of patients presenting with dyspnea to emergency departments.

It is difficult, however, to disregard the dramatic finding of the BASEL study, and some of the utility of BNP may have been related to the way in which it was interpreted in the study. The study utilized two separate diagnostic cutoffs for BNP: a level of $100 \mathrm{pg} / \mathrm{ml}$ to rule out HF and a level of $500 \mathrm{pg} / \mathrm{ml}$ to rule in HF. Our determinations of the performance characteristics of BNP support the use of two diagnostic cutoffs. The pooled likelihood ratio (LR) was 0.14 for a BNP of $<105 \mathrm{pg} / \mathrm{ml}$ (pooled sensitivity $90 \%$ and specificity $74 \%$ ). A LR of $<0.1$ can generally rule out disease independent of pre-test probability and a LR of > 10 can similarly rule in disease independent of pre-test probability [44]. LRs of between 0.1 and 0.2 or between 5 and 10 have moderate ability to rule out or rule in disease [44]. The LR of 0.14 indicates that a BNP of $<105$ will moderately lower the pre-test probability of HF, and may be clinically useful. The performance of a BNP cutoff of $500 \mathrm{pg} / \mathrm{ml}$ has not been studied; the highest cutoff we found in the literature was 399. In this highest cutoff range of $300-400 \mathrm{pg} / \mathrm{ml}$, the pooled LR for a positive test, or elevated BNP, is 7.6, which represents moderate ability to rule in HF. It is possible that using a higher cutoff of 500 would perform better. Clearly, though, a lower cutoff to rule out HF and a higher cutoff to rule in HF is supported by the evidence, and has in fact been adopted in practice guidelines [51].

Our study has some methodological limitations. We pooled data from different studies with obvious heterogeneity, utilizing the random effects model to determine pooled LRs. We opted to perform pooling despite the heterogeneity because we believe that there is a clinical need for a compilation of findings regarding BNP, so that clinicians may understand its utility in clinical practice. We utilized the random effects model to minimize the bias associated with heterogeneous results, but the validity of the pooled estimates may still be limited by the presence of heterogeneity. In addition, we were limited by the quality of the available data, which was not ideal.

\section{Conclusion}

In summary, our analysis suggests that BNP performs moderately as a diagnostic test for HF in the emergency department, with very high and very low values contributing significantly to making a diagnosis. Most of the studies recruited a wide spectrum of patients presenting with dyspnea, including patients with diagnostic uncertainty as well as patients with more apparent diagnoses in whom a diagnostic test might not be used in clinical practice. In order to clarify the true performance of this diagnostic test among patients in whom it is needed, studies which include only patients with diagnostic uncertainty should be performed. Until then, BNP can be best utilized by interpreting separate cutoffs for ruling in HF and ruling out HF. The BASEL study provides good evidence of the utility of BNP in a more severely ill population in Switzerland, but its findings may not be generalizable to different populations.

\section{Abbreviations}

BNP Brain natriuretic peptide

COPD Chronic obstructive pulmonary disease

\section{ED Emergency department}

\section{HF Heart failure}

\section{LR Likelihood ratio}

NTproBNP N-terminal probrain natriuretic peptide

$\mathrm{pg} / \mathrm{ml}$ picograms per milliliter

\section{Competing interests}

The author(s) declare that they have no competing interests.

\section{Authors' contributions}

DK participated in the design of the study, performed searches, reviewed articles, performed quality assessments and drafted the manuscript. JPW participated in the design of the study and performed the statistical analysis. PW participated in the design of the study and edited the manuscript. RA and DP performed searches and reviewed articles. TM participated in the design of the study, performed quality assessments and edited the manuscript. All authors have read and approved the final manuscript.

\section{Acknowledgements}

The authors wish to thank Patrick Ray, Paul Clopton and Alan Maisel for kindly providing unpublished data from their clinical trials.

\section{References}

I. Hunt SA, Baker DW, Chin MH, Cinquegrani MP, Feldman AM, Francis GS, Ganiats TG, Goldstein S, Gregoratos G, Jessup ML, Noble RJ, Packer M, Silver MA, Stevenson LW: ACC/AHA Guideline Update for the Diagnosis and Management of Chronic Heart Failure in the Adult-Summary Article. Circulation 2005, I I 2(12): I 825-1852.

2. Thom T, Haase N, Rosamond W, Howard V: Heart Disease and Stroke Statistics-2006 Update. Circulation 2006, I 3(6):e85-el5I.

3. Hobbs RE: Guidelines for the Diagnosis and Management of Heart Failure. American Journal of Therapeutics 2004, I I:467-472.

4. Nieminen MS, Bohm M, Cowie MR: Executive summary of the guidelines on the diagnosis and treatment of acute heart fail- 
ure: The Task Force on Acute Heart Failure of the European Society of Cardiology. European Heart Journal 2005, 26:384-4I6.

5. Schwam E: B-type Natriuretic Peptide for Diagnosis of Heart Failure in Emergency Department Patients: A Critical Appraisal. Academic Emergency Medicine 2004, I I:686-69 I.

6. Jaeschke R, Gyatt GH, Sackett DL: Users' guides to the medical literature. III. How to use an article about a diagnostic Test. B. What are the results and will they help me in caring for my patients? The Evidence- Based Medicine Working Group. Journal of the American Medical Association 1994, 27 I(9):703-707.

7. Irwig L, Tosteson ANA, Gatsonis C, Lau J, Colditz G, Chalmers TC, Mosteller F: Guidelines for meta-analyses evaluating diagnostic tests. Annals of Internal Medicine 1994, I 20(8):667-676.

8. Tatsioni A, Zarin DA, Aronson N, Samson DJ, Flamm C, Schmid C Lau J: Challenges in Systematic Reviews of Diagnostic Technologies. Annals of Internal Medicine 2005, 142(12 (Part 2)): $1048-1055$.

9. Bossuyt PM, Retsma JB, David E. Bruns DE, Constantine A. Gatsonis CA, Glasziou PP, Irwig LM, Moher D, Rennnie D, de Vet HCW, Lijmer JG: The STARD Statement for Reporting Studies of Diagnostic Accuracy: Explanation and Elaboration. Annals of Internal Medicine 2003, I 38(I):WI-WI2.

10. Wang CS, FitzGerald JM, Schulzer M, Mak E, Ayas NT: Does This Dyspneic Patient in the Emergency Department Have Congestive Heart Failure? Journal of the American Medical Association 2005, 294( ( 5): 1944-1956.

II. Doust JA, Glasziou PP, Pietrzak E, Dobson A: A Systematic Review of the Diagnostic Accuracy of Natriuretic Peptides for Heart Failure. Archives of Internal Medicine 2004, 164:1978-1984.

12. Remme WJ, Swedberg K: Guidelines for the diagnosis and treatment of chronic heart failure. European Heart Journal 200I, 22:1527-1560

13. Whiting P, Rutjes AWS, Reitsma JB, Bossuyt PMM, Kleijnen J: The development of QUADAS: a tool for the quality assessment studies of diagnostic accuracy included in systematic reviews. BMC Medical Research Methodology 2003, 3:25-38.

14. Begg CB: Biases in the assessment of diagnostic tests. Statistics in Medicine 1987, 6(14):41 I-423.

15. Kesley JL, Evan AS: Methods in Observational Epidemiology. 2nd ed. ed. New York, NY, Oxford University Press; 1996.

16. Maclure M, Willett WC: Misinterpretation and misuse of the kappa statistic. American Journal Of Epidemiology 1987, 126(2): $161-169$

17. Higgins JPT, Thompson SG, Deek J, Altman DG: Measuring inconsistency in meta-analysis. BM/ 2003, 327(74I4):557-560.

18. Deville WL, Buntinx F, Bouter LM, Montori VM, de Vet HCW, van der Windt DAWM, Bezemer PD: Conducting systematic reviews of diagnostic studies: didactic guidelines. BMC Medical Research Methodology 2002, 2:9.

19. Deeks J, Macaskill P, Irwig L: The performance of tests of publication bias and other sample size effects in systematic reviews of diagnostic test accuracy was assessed. Journal of Clinical Epidemiology 2005, 58(9):882-893.

20. Egger M, Smith GD, Schneider M, Minder C: Bias in meta-analysis detected by a simple, graphical test. BMJ 1997, 3 I 5(7 I09):629-634

21. Jourdain P, Funck F, Canault E, Bellorini M, Deschamps P, Duval G, Duboc $D$, Desnos M: Apports du peptide natriuretique de type $B$ dans la prise en charge aux urgences des patients suspects d'insuffisance cardiaque. Archives des maladies du coeur et des vaisseaux 2002, 95(9):763-767.

22. Begg CB: Publication Bias. In The Handbook of Research Synthesis Edited by: Cooper H, Hedges LV. New York, N.Y., Russell Sage Foundation; 1994

23. Steg P, Joubin L, McCord J, Abraham WT, Hollander J, Omland T, Mentre F, McCullough P, Maisel AS: B-type natriuretic peptide and echocardiographic determination of ejection fraction in the diagnosis of congestive heart failure in patients with acute dyspnea. Chest 2005, I 28(I):2I-29.

24. Knudsen CW, Westheim A, Omland T: B-type natriuretic peptide and clinical judgement in the diagnosis of heart failure in patients presenting with acute dyspnoea. Tidsskr Nor Laegeforen 2003, I 23(I 5):2045-2048.

25. Dao Q, Krishnaswamy P, Kazanegra R: Utility of B-Type Natriuretic Peptide in the Diagnosis of Congestive Heart Failure in an Urgent-Care Setting. Journal of the American College of Cardiology 200I, 37:379-385.

26. Knudsen CW, Riis JS, Finsen AV, Eikvar L, Muller C, Westheim A, Omland T: Diagnostic value of a rapid test for B-type natriuretic peptide in patients presenting with acute dyspnoe: effect of age and gender. European Journal of Heart Failure 2004, 6:55-62.

27. Maisel A, Clopton P, Krishnaswamy P: Impact of age, race and sex on the ability of B-type natriuretic peptide to aid in the emergency diagnosis of heart failure: Results from the Breathing Not Properly (BNP) multinational study. American Heart Journal 2004, 147:1078-1084.

28. Maisel A, McCord J, Nowak R, Hollander J, Wu AHB, Duc P, Omland T, Storrow AB, Krishnaswamy P, Abraham WT, Clopton P, Steg P, Aumont MC, Westheim A, Knudsen CW, Perez A, Kamin R, Kazanegra R, Herrmann HC, McCullough P: Bedside B-Type natriuretic peptide in the emergency diagnosis of heart failure with reduced or preserved ejection fraction. Results from the Breathing Not Properly Multinational Study. Journal of the American College of Cardiology 2003, 4 I (I I):20I0-20I7.

29. Maisel AS, Krishnaswamy P, Nowak RM, McCord J, Hollander JE, Duc P, Omland T, Storrow AB, Abraham WT, Wu AHB, Clopton P, Steg P. Westheim A, Knudsen CW, Perez A, Kazanegra R, Herrmann HC, McCullough PA: Rapid Measurement of B-Type Natriuretic Peptide in the Emergency Diagnosis of Heart Failure. New England Journal of Medicine 2002, 347:161-167.

30. McCullough PA, Hollander J, Nowak R, Storrow AB, Duc P, Omland $T$, McCord J, Herrmann HC, Steg P, Westheim A, Knudsen CW, Abraham WT, Lamba S, Wu AHB, Perez A, Clopton P, Krishnaswamy $P$, Kazanegra $R$, Maisel A: Uncovering Heart Failure in Patients with a History of Pulmonary Disease: Rationale for the Early Use of B-type Natriuretic Peptide in the Emergency Department. Academic Emergency Medicine 2003, I0(3): 198-204.

31. McCullough PA, Nowak R, McCord J, Hollander J, Herrmann HC Steg $P$, Duc $P$, Westheim $A$, Omland T, Knudsen CW, Storrow $A B$, Abraham WT, Lamba S, Wu AHB, Perez A, Clopton P, Krishnaswamy P, Kazanegra R, Maisel A: B-Type Natriuretic Peptide and Clinical Judgement in Emergency Diagnosis of Heart FailureAnalysis From Breathing Not Properly (BNP) Multinational Study. Circulation 2002, 106(4):416-422.

32. Morrison LK, Harrison A, Krishnaswamy P, Kazanegra R, Clopton P, Maisel A: Utility of a Rapid B-Natriuretic Peptide Assay in Differentiating Congestive Heart Failure from Lung Disease in Patients Presenting with Dyspnea. Journal of the American College of Cardiology 2002, 39(2):202-209.

33. Knudsen CW, Omland T, Clopton P, Westheim A, Abraham WT, Storrow AB, McCord J, Nowak R, Aumont, Duc P, Hollander J, Wu $A H B, M c C u l l o u g h$, Maisel A: Diagnostic value of $B-T y p e$ natriuretic peptide and chest radiographic findings in patients with acute dyspnea. American Journal of Medicine 2004, I I 6(6):363-368.

34. A M, Clopton, al K: Impact of age, race, and sex on the ability of B-type natriuretic peptide to aid in the emergency diagnosis of heart failure: Results from the Breathing Not Properly (BNP) multinational study. American Heart Journal 2004, 147:1078-1084

35. Ray P, Arthaud M, Birolleau S, Isnard R, Lefort $Y$, Boddaert J, Riou B Comparison of brain natriuretic peptide and probrain natriuretic peptide in the diagnosis of cardiogenic pulmonary edema in patients aged 65 and older. Journal of the American Geriatrics Society 2005, 53(4):643-648.

36. Ray P, Arthaud M, Lefort Y, Birolleau S, Beigelman C, Riou B: Usefulness of B-type natriuretic peptide in elderly patients with acute dyspnea. Intensive Care Medicine 2004, 30:2230-2236.

37. Alibay Y, Beauchet A, El Mahmoud R, Schmitt C, Brun-Ney D, Benoit MO, Dubourg O, Boileau C, Jondeau G, Puy H: Plasma N-terminal pro-brain natriuretic peptide and brain natriuretic peptide in assessment of acute dyspnea. Biomedicine \& Pharmacotherapy 2005, 59:20-24.

38. Lainchbury JG, Campbell E, Frampton CM, Yandle TG, Nicholls MG, Richards AM: Brain Natriuretic Peptide and N-Terminal Brain Natriuretic Peptide in the Diagnosis of Heart Failure in Patients with Acute Shortness of Breath. Journal of the American College of Cardiology 2003, 42(4):728-735.

39. Logeart D, Saudubray C, Byne P, Thabut G, Ennezat PV, Chavelas C, Zanker C, Bouvier E, Solal AC: Comparative Value of Doppler Echocardiography and B-Type Natriuretic Peptide Assay in 
the Etiologic Diagnosis of Acute Dyspnea. Journal of the American College of Cardiology 2002, 40(1 0): 1794-1800.

40. Villacorta H, Duarte A, Duarte NM, Carrano A, Mesquita ET, Dohmann HJF, Gerreira FEG: The Role of B-Type Natriuretic Peptide in the Diagnosis of Congestive Heart Failure in Patients Presenting to an Emergency Department with Dyspnea. Arquivos brasileros de cardiologia 2002, 79(6):569-572.

4I. Mueller T, Gegenhuber A, Poelz W, Haltmayer M: Diagnostic accuracy of $B$ type natriuretic peptide and amino terminal proBNP in the emergency diagnosis of heart failure. Heart 2005, $91: 606-612$.

42. Davis M, Espiner E, Richards G, Billings J, Town I, Neill A, Drennan C, Richards M, Turner J, Yandle T: Plasma brain natriuretic peptide in assessment of acute dyspnoea. The Lancet 1994, 343:440-444.

43. Pfister R, Schneider CA: Natriuretic peptides BNP and NT-proBNP: established laboratory markers in clinical practice or just perspectives? Clinica Chimecta Acta 2004, 349:25-38.

44. Guyatt G, Rennie D: Users' Guides to the Medical Literature. The Evidence-Based Medicine Working Group. Chicago, Illinois, AMA Press; 2002.

45. Montori VM, Wyer P, Newman TB, Keitz S, Guyatt G: Tips for learners of evidence-based medicine: 5 . The effect of spectrum of disease on the performance of diagnostic tests. Canadian Medical Association Journal 2005, I 73(4):385-390.

46. Guyatt G, Tugwell PX, Feeny DH, Haynes RB, Drummond M: A framework for clinical evaluation of diagnostic tests. Canadian Medical Association Journal 1986, 134(6):587-594.

47. Deyo RA, Jarvik JJ: New Diagnostic Tests: Breakthrough Approaches or Expensive Add-Ons? Annals of Internal Medicine 2003, I39(II):950-95I.

48. Mueller C, Scholer A, Laule-Kilian K, Martina B, Schindler C, Buser P, Pfisterer M, Perruchoud A: Use of B-Type Natriuretic Peptide in the Evaluation and Management of Acute Dyspnea. New England Journal of Medicine 2004, 350(7):647-654.

49. Schwam E: Rapid measurement of B-type natriuretic peptides reduced time to discharge and treatment costs in patients with acute dyspnea [Letter]. ACP Journal Club 2005, I 42(I):A-I 4 .

50. Schunemann HJ, Akl E: Rapid measurement of B-type natriuretic peptides reduced time to discharge and treatment costs in patients with acute dyspnea [comment]. ACP Journal Club 2004, I II(2):35.

5I. Silver MA, Maisel A, Yancy C, McCullough PA, Burnett JC, Francis GS, Mehra MR, Peacock WF IV, Gonarow G, Gibler WB, Morrow DA, Hollander ]: BNP Consensus Panel 2004: A Clinical Approach for the Diagnostic, Prognostic, Screening, Treatment Monitorying, and Therapeutic Roles of Natriuretic Peptides in Cardiovascular Diseases. Congestive Heart Failure 2004, I 0(5 Supplement 3):.

\section{Pre-publication history}

The pre-publication history for this paper can be accessed here:

http://www.biomedcentral.com/1471-227X/7/6/prepub

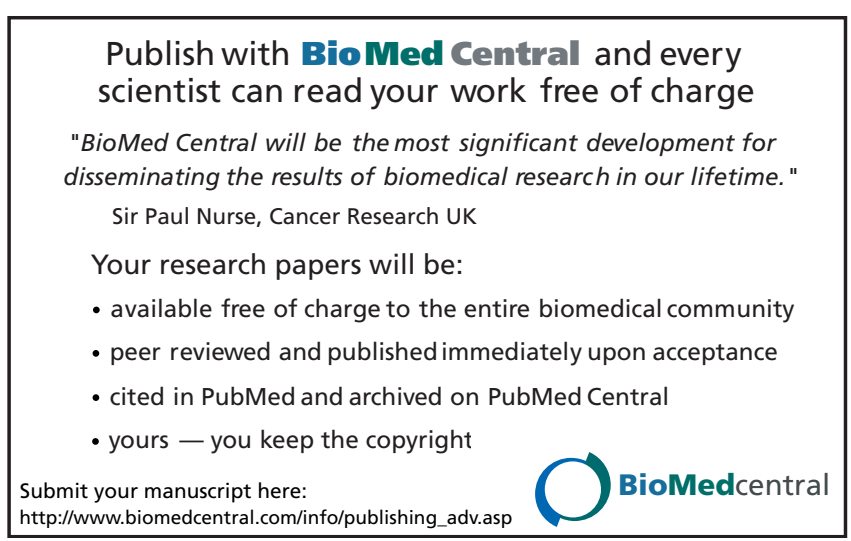

